\title{
Remission in Major Depressive Disorder: A Comparison of Pharmacotherapy, Psychotherapy, and Control Conditions
}

\begin{abstract}
Nicola Casacalenda, M.D.
J. Christopher Perry, M.P.H., M.D.

Karl Looper, M.D.

Objective: The aim of this study was to assess the percentages of full remission in studies of patients with major depressive disorder in which pharmacotherapy, psychotherapy, and control conditions were directly compared.
\end{abstract}

Method: Computerized searches of the MEDLINE and PsychINFO databases up to November 2000 were used to identify six multiple-cell randomized, controlled, double-blind trials for well-defined major depressive disorder in which medications, psychotherapy, and control conditions were directly compared and for which remission percentages were reported.

Results: The studies included a total of 883 outpatients with mild to moderate, primarily nonmelancholic, nonpsychotic major depressive disorder. Treatment duration ranged from 10 to 34 weeks (median=16 weeks). An intent-to-treat analysis indicated that, according to measurements by independent blind raters, antidepressant medication (tricyclic antidepressants and phenelzine) and psychotherapy (primarily cognitive behavior and interpersonal therapies) were more efficacious than control conditions, but there were no differences between active treatments. The percentages of remission for all patients randomly assigned to medication, psychotherapy, and control conditions were $46.4 \%, 46.3 \%$, and $24.4 \%$, respectively. Furthermore, significantly more patients dropped out of control conditions $(54.4 \%)$ than either treatment with medication $(37.1 \%)$ or psychotherapy $(22.2 \%)$.

Conclusions: Both antidepressant medication and psychotherapy may be considered first-line treatments for mildly to moderately depressed outpatients.
$\mathrm{M}$ $17.1 \%$ of individuals during their lifetimes (1). Major depressive disorder is a major health problem associated with gradual and often incomplete recovery $(2,3)$, significant limitations in functioning and well-being (4-6), greater risk of mortality due to medical illness (7), increased utilization of health services (7), and tremendous costs to society (8).

Fortunately, there are a number of efficacious medications and/or psychotherapies from which clinicians may choose when treating a depressed patient $(9,10)$. Several meta-analyses comparing the efficacy of these treatments have been published (10-13). However, these meta-analyses have several methodological limitations. First, several (11-13) included studies that did not require the use of standardized diagnostic criteria for major depressive disorder and studies of less severely "depressed" student groups. Second, some $(12,13)$ did not separate treatment effects on the basis of the type of analysis performed (completer versus intent-to-treat). Third, no attempt was made in any of the meta-analyses to ensure that the treatments were "validly compared, within assay-sensitive randomized studies," as recently suggested by Klein (14), which raises concerns about the validity of the compari- sons. Finally, efficacy was measured in terms of effect size (11-13) or response to treatment (10), usually defined as a reduction of at least $50 \%$ in the score on a depression rating scale. A limitation of this approach is that some "responders" may still have a substantial degree of residual depressive symptoms, which increases the risk of relapse, social and vocational impairment, and suicide $(6,15-19)$. Therefore, it may be more clinically meaningful to measure efficacy in terms of full remission, defined as "a relatively brief...period during which...the individual is asymptomatic (i.e., no longer meets syndromal criteria for the disorder and has no more than minimal symptoms)" (20).

In this review we examine the comparative efficacy of pharmacotherapy and psychotherapy for major depressive disorder. Although several similar meta-analyses have already been published, we aim to overcome the limitations of previous meta-analyses by including only multiple-cell randomized, controlled trials that directly compared pharmacotherapy, psychotherapy, and control conditions for patients with well-defined major depressive disorder and by using full remission as the main dependent variable. To our knowledge, ours is the first review to use such methods, making it a useful addition to the meta-analytic literature on the topic. 


\section{Method}

Treatment studies of major depressive disorder were identified by using computerized searches of the MEDLINE and PsychINFO databases up to November 2000. The key terms "depressive disorder" and "major depression" were used with their subheadings "drug therapy" / "therapy" and "treatment and prevention," respectively, for MEDLINE and PsychINFO. This process was complemented by a manual search of references cited in retrieved articles and pertinent reviews on the topic. The included studies 1) were published in English-language journals, 2) focused on adults, 3) used standardized diagnostic criteria for major depressive disorder, 4) used a multiple-cell randomized, controlled trial design, and 5) were reported with sufficient data to allow the calculation of remission percentages. Published articles by the same research group that focused on the same study group were pooled to ensure the independence of studies included in our review. Our inclusion criteria were met by six main articles (21-26) presenting efficacy data and seven companion articles (27-33) with additional relevant data.

Remission was calculated by using both completers and intent-to-treat groups, as available. However, it should be noted that in one study (25) all patients in the treatment-as-usual control group were considered completers unless they refused to be contacted for follow-up. Furthermore, whereas for most studies the intent-to-treat data were based on a last-observation-carriedforward analysis of all patients randomly assigned to treatment, one study (21) examined the remission status of all patients at the end of the study, including dropouts who had received further nonrandomized treatment, while in another (23) all dropouts were considered to be "not recovered."

Data analysis was performed by using SAS, version 8.0 (Cary, N.C., SAS Institute). Categorical variables were tested by using the chi-square statistic. Continuous variables were examined by using general linear model procedures followed by Duncan's multiple range test for multiple comparisons. All significance tests were performed at a two-tailed alpha level of 0.05 .

\section{Results}

\section{Description of Studies}

The patients, treatments, and study designs in the six studies are summarized in Table 1 . This review includes 883 evaluable patients—261 receiving medication, 352 receiving psychotherapy, and 270 in control groups. The mean age reported in each study ranged from 32 to 40 years, and $76.5 \%$ of the patients were female (range $=68 \%-$ 85\%). All patients were diagnosed as having nonpsychotic major depression, albeit with various diagnostic methods, including the Research Diagnostic Criteria (based on either the Schedule for Affective Disorders and Schizophrenia [21, 22] or a nonstructured clinical assessment [24]), the Structured Clinical Interview for DSM-III (23) or DSMIII-R (26), and the Diagnostic Interview Schedule for DSMIII-R (25). The mean baseline score on the Hamilton Depression Rating Scale varied between 15.3 and 19.7 in all studies except one (25). In the three studies for which episode duration was reported, this period varied widely: median=13.4 weeks (23), mean=8.4 months (24), and mean= 58.3 months (25). The percentage of patients with chronic major depression was not reported for any of the studies. The percentage of patients with recurrent major depres- sive disorder ranged from $40 \%$ in one study (24) to approximately $62 \%$ in three others $(21,22,26)$. The percentage of patients with endogenous depression ranged from $7.4 \%$ in one study (26) to approximately $35 \%$ in two others $(21,22)$. The percentages of patients with melancholia were $2.8 \%$ in one study (26) and $18 \%$ in another (23). The percentage of patients with atypical depression varied from $29.7 \%$ in one study (22) to $100 \%$ in another (26). The percentage of comorbid dysthymia was $30 \%$ in one study (22), and in another (25) the percentages of lifetime panic disorder and generalized anxiety disorder were $44.2 \%$ and $62.4 \%$, respectively. The percentages of personality disorders were reported for four studies: $8.3 \%$ (26), 36.5\% (23), 68\% (25), and $74 \%(22)$.

In five studies (21-25) tricyclic antidepressants were used, while another (26) involved phenelzine. Cognitive behavior therapy was used in three studies $(22,23,26)$, interpersonal therapy in three $(21,22,25)$, problem solving in one (24), and social work counseling in another (23). All psychotherapies were delivered in an individual format. The control conditions were pill placebo plus clinical management in three studies $(22,24,26)$, treatment as usual by a general physician (in which approximately $45 \%$ of patients received antidepressant medications) in two studies $(23,25)$, and low-intensity supportive therapy in one study (21). Treatment duration ranged from 10 to 16 weeks in all studies except that by Schulberg et al. (25), which lasted approximately 8 months; the overall median was 16 weeks. The doses of amitriptyline were 100-200 $\mathrm{mg} /$ day (21), $\geq 150 \mathrm{mg} /$ day (23), and a mean of $139 \mathrm{mg} /$ day (24). The mean dose of imipramine was $185 \mathrm{mg} /$ day (22). The mean phenelzine dose was $64 \mathrm{mg} /$ day (26). For nortriptyline, blood levels were 190-570 nmol/liter (25). The mean number of psychotherapy sessions received ranged from six (24) to a maximum of $20(22,26)$.

In each of the six studies the subjects were outpatients. Three studies $(21,22,26)$ were performed in psychiatric settings, whereas three others (23-25) were carried out in primary care settings. Although all studies were randomized, the randomization process of only three (22-24) was described adequately and followed the guidelines suggested by Jadad et al. (34). Every study using a pill placebo as a control $(22,24,26)$ was double-blind. In all of the studies, independent evaluators blind to the type of treatment received by patients were used to assess outcome.

Remission is generally defined as achievement of a score that falls below a predetermined cutoff on a depression rating scale. More specifically, a score of 7 or less on the Hamilton depression scale is required in one consensus definition (20). This definition was used in only two $(24,25)$ of the six studies. In three others $(22,23,26)$ remission was defined as a score of 6 or less on the Hamilton depression scale, while in another (21) the criterion was a score of 5 or less on the Raskin Depression Scale. Remission was not required to be sustained over any given period of time in any of the six studies. Finally, multiple ver- 
TABLE 1. Multiple-Cell Randomized, Controlled Trials Comparing Medication, Psychotherapy, and Control Conditions for Major Depression

\begin{tabular}{|c|c|c|c|c|c|c|c|c|c|}
\hline \multirow[b]{3}{*}{ Study and Treatment Types } & \multirow{3}{*}{$\begin{array}{l}\text { Weeks of } \\
\text { Treatment }\end{array}$} & \multirow{3}{*}{$\begin{array}{l}\text { Mean Baseline } \\
\text { Score on Hamilton } \\
\text { Depression } \\
\text { Rating Scale }\end{array}$} & \multirow{3}{*}{$\begin{array}{l}\text { Definition } \\
\text { of Remission }\end{array}$} & \multicolumn{3}{|c|}{$\begin{array}{l}\text { Patients Who } \\
\text { Completed Study }\end{array}$} & \multicolumn{3}{|c|}{$\begin{array}{l}\text { Patients in Intent-to- } \\
\text { Treat Analysis }\end{array}$} \\
\hline & & & & \multirow[b]{2}{*}{$\mathrm{N}$} & \multicolumn{2}{|c|}{ Remission } & \multirow[b]{2}{*}{$\mathrm{N}$} & \multicolumn{2}{|c|}{ Remission } \\
\hline & & & & & $\mathrm{N}$ & $\%$ & & $\mathrm{~N}$ & $\%$ \\
\hline Herceg-Baron et al., $1979(21)^{\mathrm{a}}$ & 16 & & $\begin{array}{l}\text { Raskin Depression } \\
\text { Scale score } \leq 5\end{array}$ & & & & & & \\
\hline Amitriptyline & & 16.8 & & 8 & 5 & 62.5 & 20 & 7 & 35.0 \\
\hline Interpersonal therapy & & 17.3 & & 12 & 6 & 50.0 & 17 & 7 & 41.2 \\
\hline Supportive therapy ("as needed") & & 15.3 & & 7 & 6 & 85.7 & 21 & 7 & 33.3 \\
\hline Elkin et al., $1989(22)^{\mathrm{b}}$ & 16 & & $\begin{array}{l}\text { Hamilton depression } \\
\text { scale score } \leq 6\end{array}$ & & & & & & \\
\hline Imipramine & & 19.5 & & 37 & 21 & 56.8 & 57 & 24 & 42.1 \\
\hline Cognitive behavior therapy & & 19.6 & & 37 & 19 & 51.4 & 59 & 21 & 35.6 \\
\hline Interpersonal therapy & & 19.6 & & 47 & 26 & 55.3 & 61 & 26 & 42.6 \\
\hline Pill placebo & & 19.5 & & 34 & 10 & 29.4 & 62 & 13 & 21.0 \\
\hline Scott et al., $1992(23)^{\mathrm{C}}$ & 16 & & $\begin{array}{l}\text { Hamilton depression } \\
\text { scale score } \leq 6\end{array}$ & & & & & & \\
\hline Amitriptyline & & 18.2 & & - & - & - & 26 & 15 & 57.7 \\
\hline Beck's cognitive therapy & & 18.3 & & - & - & - & 29 & 12 & 41.4 \\
\hline Social work counseling & & 15.7 & & - & - & - & 29 & 21 & 72.4 \\
\hline Treatment as usual & & 19.7 & & - & - & - & 29 & 14 & 48.3 \\
\hline Mynors-Wallis et al., 1995 (24) d & 12 & & $\begin{array}{l}\text { Hamilton depression } \\
\text { scale score } \leq 7\end{array}$ & & & & & & \\
\hline Amitriptyline & & 19.1 & & - & - & - & 31 & 16 & 51.6 \\
\hline Problem solving & & 19.4 & & - & - & - & 30 & 18 & 60.0 \\
\hline Pill placebo & & 18.4 & & - & - & - & 30 & 8 & 26.7 \\
\hline Schulberg et al., $1996(25)^{\mathrm{e}}$ & 34 & & $\begin{array}{l}\text { Hamilton depression } \\
\text { scale score } \leq 7\end{array}$ & & & & & & \\
\hline Nortriptyline & & 23.7 & & 30 & 20 & 66.7 & 91 & 44 & 48.4 \\
\hline Interpersonal therapy & & 22.3 & & 39 & 28 & 71.8 & 91 & 42 & 46.2 \\
\hline Treatment as usual & & 23.4 & & 81 & 16 & 19.8 & 92 & 17 & 18.5 \\
\hline Jarrett et al., $1999(26)^{f}$ & 10 & & $\begin{array}{l}\text { Hamilton depression } \\
\text { scale score } \leq 6\end{array}$ & & & & & & \\
\hline Phenelzine & & 16.8 & & - & - & - & 36 & 15 & 41.7 \\
\hline Beck's cognitive therapy & & 18.4 & & - & - & - & 36 & 16 & 44.4 \\
\hline Pill placebo & & 17.4 & & - & - & - & 36 & 7 & 19.4 \\
\hline
\end{tabular}

a This study also contained a combined-treatment cell, which is not shown here. No statistical analyses were reported.

${ }^{b}$ The intent-to-treat analysis showed that imipramine and interpersonal therapy were significantly superior to placebo. In the analysis of completers, the findings were similar but nonsignificant.

c Social work counseling was superior to treatment as usual.

d Amitriptyline and problem-solving therapy were superior to placebo.

e In both the completer and intent-to-treat analyses, nortriptyline and interpersonal therapy were superior to placebo.

${ }^{f}$ All patients studied had major depressive disorder with atypical features. No statistically significant difference was found between treatment groups according to the stated definition of remission. However, both phenelzine and Beck's cognitive therapy were superior to placebo when a score of 9 or less on the Beck Depression Inventory was used as the definition of remission.

sions of the Hamilton depression scale were used across the studies: unspecified (23), the 17-item version (22, 24, 25), and the 21-item version (26).

\section{Substantive Findings}

Reports on two studies $(23,25)$ did not adequately describe the number of withdrawals and dropouts. Among those that did $(21,22,24,26)$, significantly more patients dropped out of the control groups (80 of $147,54.4 \%$; four treatment groups) than either the medication groups (46 of $124,37.1 \%$; four treatment groups) or the psychotherapy groups ( 45 of $203,22.2 \%$; five treatment groups) $\left(\chi^{2}=\right.$ $38.54, \mathrm{df}=2, \mathrm{p}<0.0001)$.

Response percentages were available for only one of the six original studies (Elkin et al., reported in reference 35), thereby limiting analyses comparing the percentages of patients who responded and those who had remissions by treatment type. Nonetheless, in the study by Elkin's group
(22), intent-to-treat analyses indicated that significantly fewer patients, overall, achieved full remission (84 of 239, $35.1 \%)$ than response $(116$ of $239,48.5 \%)\left(\chi^{2}=8.26, \mathrm{df}=1, \mathrm{p}=\right.$ $0.004)$. However, none of the differences for the individual treatment types achieved statistical significance, probably because of a lack of statistical power.

Intent-to-treat analysis indicated that pharmacotherapy and psychotherapy were significantly more efficacious than control conditions but were not significantly different from each other; the percentages of remission were $46.4 \%$ for medication (six treatment groups), $46.3 \%$ for psychotherapy (eight treatment groups), and $24.4 \%$ for the control conditions (six treatment groups) $\left(\chi^{2}=37.52\right.$, $\mathrm{df}=2, \mathrm{p}<0.0001$ ). This finding persisted despite sensitivity analyses that excluded the studies by Herceg-Baron et al. (21) (in which $60 \%$ of the patients receiving medication dropped out before study termination), Schulberg et al. (25) (which included more severely depressed patients, 
TABLE 2. Overall Percentages of Remission in Six Multiple-Cell Randomized, Controlled Trials Comparing Medication, Psychotherapy, and Control Conditions for Major Depression ${ }^{a}$

\begin{tabular}{|c|c|c|c|c|c|c|c|c|c|c|c|c|c|}
\hline \multirow[b]{3}{*}{ Group } & \multicolumn{3}{|c|}{ Medication } & \multicolumn{3}{|c|}{ Psychotherapy } & \multicolumn{3}{|c|}{ Control Conditions } & & & & \\
\hline & \multirow{2}{*}{$\begin{array}{l}\text { Number } \\
\text { of } \\
\text { Treatment } \\
\text { Groups }\end{array}$} & \multicolumn{2}{|c|}{$\begin{array}{l}\text { Percent of } \\
\text { Patients With } \\
\text { Remission }\end{array}$} & \multirow{2}{*}{$\begin{array}{l}\text { Number } \\
\text { of } \\
\text { Treatment } \\
\text { Groups }\end{array}$} & \multicolumn{2}{|c|}{$\begin{array}{l}\text { Percent of } \\
\text { Patients With } \\
\text { Remission }\end{array}$} & \multirow{2}{*}{$\begin{array}{l}\text { Number } \\
\text { of } \\
\text { Treatment } \\
\text { Groups }\end{array}$} & \multicolumn{2}{|c|}{$\begin{array}{l}\text { Percent of } \\
\text { Patients With } \\
\text { Remission }\end{array}$} & \multicolumn{3}{|c|}{$\begin{array}{c}\text { Analysis } \\
\text { of Variance }\end{array}$} & \multirow{2}{*}{$\begin{array}{l}\text { Significant } \\
\text { Pairwise } \\
\text { Comparisons }\end{array}$} \\
\hline & & Mean & SD & & Mean & SD & & Mean & SD & $\mathrm{F}$ & df & $\mathrm{p}$ & \\
\hline Completers & 3 & 62.3 & 5.0 & 4 & 57.0 & 10.2 & 3 & 45.0 & 35.6 & 0.57 & 2,7 & 0.59 & \\
\hline $\begin{array}{l}\text { Patients in } \\
\text { intent-to- } \\
\text { treat } \\
\text { analysis }\end{array}$ & 6 & 46.2 & 8.2 & 8 & 47.9 & 12.0 & 6 & 27.7 & 11.4 & 6.82 & 2,17 & 0.007 & $\begin{array}{l}\text { Medication and } \\
\text { psychotherapy } \\
\text { superior to } \\
\text { control conditions }\end{array}$ \\
\hline
\end{tabular}

a The six trials are summarized in Table 1.

was much longer in duration, and in which $67 \%$ of the patients receiving medication dropped out before study termination), and Jarrett et al. (26) (in which all patients had atypical depressive features), individually or as a group. Similar findings were obtained for the completers: the percentages of remission were similar for medication $(61.3 \%$, 46 of 75 , three treatment groups) and psychotherapy (58.5\%, 79 of 135, four treatment groups), and those percentages were both higher than the percentage for control conditions $\left(26.2 \%, 32\right.$ of 122 , three treatment groups) $\left(\chi^{2}=\right.$ $34.47, \mathrm{df}=2, \mathrm{p}<0.0001)$. The findings remained after removing the study by Herceg-Baron et al. (21), which had an unusually high percentage of dropouts in the control group, resulting in an inflated estimate of remission; the percentages for medication $(61.2 \%, 41$ of 67 , two treatment groups) and psychotherapy (59.3\%, 73 of 123, three treatment groups) remained similar and higher than the percentage for control conditions $(22.6 \%, 26$ of 115 , two treatment groups) $\left(\chi^{2}=40.39, \mathrm{df}=2, \mathrm{p}<0.0001\right)$.

Next, we repeated our main analyses with a different statistical approach. More specifically, the remission percentages from the original studies were treated as continuous variables. Means of these percentages were then calculated for each treatment type across studies and were then compared by means of an F statistic. This metaanalytic approach was chosen because, contrary to our initial mega-analytic approach, it 1) is not based on the assumption that subject groups are comparable across studies, 2) provides a measure of between-study variability for remission percentages, and 3 ) is more conservative. As shown in Table 2, the results for intent-to-treat analyses were essentially unchanged; the percentages and $95 \%$ confidence intervals (CIs) were similar for psychotherapy (47.9\%, 95\% CI=37.8-57.9\%, eight treatment groups) and medication $(46.2 \%, 95 \% \mathrm{CI}=37.6-54.8 \%$, six treatment groups), and those percentages were higher than those for control conditions $(27.7 \%, 95 \% \mathrm{CI}=15.7-39.7 \%$, six treatment groups) ( $\mathrm{F}=6.82, \mathrm{df}=2,17, \mathrm{p}=0.007)$. The results were also similar after the same sensitivity analyses were performed. In contrast, the differences in efficacy among treatment groups for all completers did not reach statistical significance when the more conservative approach was used (Table 2). The differences for completers were significant after the outlier study by Herceg-Baron et al. (21) was excluded; the percentages for medication (mean= $61.8 \%, \mathrm{SD}=7.0 \%$, two treatment groups) and psychotherapy (mean $=59.5 \%, \mathrm{SD}=10.8 \%$, three treatment groups) were similar and higher than the percentage for control conditions (mean $=24.6 \%, \mathrm{SD}=6.8 \%$, two treatment groups) ( $\mathrm{F}=14.30, \mathrm{df}=2,6, \mathrm{p}=0.005)$. However, the results for completers obtained by using this approach must be interpreted with caution since the small number of studies on which they are based make them unstable estimates of remission.

Finally, although the remission percentages were significantly higher for active treatments than for control conditions (data just presented) and were higher for studies performed in primary care $(47.1 \%, 95 \% \mathrm{CI}=35.9-58.3 \%, 10$ treatment groups) than for those in psychiatric settings (35.6\%, 95\% CI=29.2-42.0\%, 10 treatment groups) ( $\mathrm{F}=6.56$, $\mathrm{df}=1,18, \mathrm{p}=0.002$ ), we found no interaction between treatment setting and treatment type $(\mathrm{F}=0.26, \mathrm{df}=2,17, \mathrm{p}=0.77)$ $(\mathrm{F}=4.95, \mathrm{df}=5,14, \mathrm{p}=0.008$, for overall model $)$.

\section{Discussion}

The novel contributions of our review are twofold. First, our focus was on remission instead of effect size (11-13) or response (10). The finding that there were significantly more patients in the Elkin et al. study (22) who responded to treatment than achieved full remission lends support to the hypothesis that some "responders" may still have a substantial degree of residual depressive symptoms, thereby confirming that the focus on full remission represents an important paradigm shift in the field. Second, to our knowledge, this is the first review that examines the comparative efficacy of pharmacotherapy and psychotherapy for major depressive disorder exclusively on the basis of the results of multiple-cell randomized, controlled trials that directly compared medications, psychotherapies, and control conditions. This approach, as suggested by others (14), is the only safeguard against noncomparability of study groups, inadequate implementation of pharmacotherapy, and nonspecific treatment effects. We also examined a more homogenously defined patient group than was covered in other meta-analyses (11-13), 
including only studies of adults meeting standardized diagnostic criteria for major depressive disorder.

Based on this approach, the main finding of this review is that both antidepressant medication (tricyclic antidepressants and phenelzine) and psychotherapy (primarily cognitive behavior therapy and interpersonal therapy) are almost twice as efficacious as control conditions in producing full remission in outpatients with primarily nonmelancholic nonpsychotic major depressive disorder of mild to moderate severity after a median of 16 weeks of treatment; i.e., intent-to-treat analysis indicated that the mean percentages of patients with remissions after active treatments were approximately $46 \%$ for medication and psychotherapy, compared to $24 \%$ for control conditions. The lower attrition percentages in the groups receiving active treatments than in those in control conditions may also reflect the greater efficacy of active treatments, although this remains speculative in the absence of adequate reporting of reasons for dropout/withdrawal for the original studies. Although our results contrast with those of Dobson (11), who concluded that cognitive therapy was more efficacious than pharmacotherapy for "depressed" patients, more recent meta-analyses $(10,12,13)$ failed to demonstrate a significant difference in efficacy between psychotherapy and medication, particularly once the effect of investigator allegiance was accounted for $(12,13)$. The finding that the percentage of remission produced by psychotherapy is similar to the percentage for medication is relevant for clinicians when treating mildly to moderately depressed outpatients with relative contraindications to medication, such as pregnancy (36) or intolerable adverse effects, and in view of reports of greater acceptability of psychotherapy for depression $(37,38)$.

The results of our review must be interpreted in the light of several potential limitations. First, the subjects in the original studies were primarily adult outpatients with unipolar, nonpsychotic major depressive disorder of mild to moderate severity. Therefore, the generalizability of our results is uncertain for child, adolescent, and elderly patients, patients with treatment-resistant, bipolar, or psychotic depression, and those with significant substance use disorders or general medical conditions, all of whom were excluded from the original randomized, controlled trials. Second, the results may or may not be generalizable to the newer antidepressants, which have largely replaced tricyclic antidepressants as first-line medications for major depressive disorder. Furthermore, treatments delivered in controlled trials are rarely carried out under routine clinical conditions (39). For example, whereas an ineffective antidepressant would be continued for 10-16 weeks in controlled trials, two antidepressant trials could be performed in a similar time frame in routine clinical practice. These factors may have led to an underestimation of the efficacy of antidepressant medication in the original multiple-cell randomized, controlled trials, a possibility that is supported by the results of a recent open- label study (40). Similarly, in clinical practice, when a patient fails to improve with a manualized psychotherapy, a good psychotherapist might shift to a different therapeutic approach. Hence, these studies may underestimate the efficacy of psychotherapy as well. Regarding treatment setting, three studies were performed in primary care (23$25)$, while three others $(21,22,26)$ were carried out in psychiatric settings. Although the likelihood of achieving remission was found to be significantly greater for patients in primary care than in psychiatric settings, no interaction was found between treatment setting and treatment type.

Third, the reports on the original studies often failed to include data on illness characteristics that may affect the interpretation of results, such as comorbidity and the percentage of patients with chronic, atypical, or melancholic depression. For example, given that approximately $28 \%-$ $42 \%$ of depressed clinic patients have atypical features (41-43) and that imipramine has been shown to be less efficacious than cognitive behavior therapy for atypical depression (35), it is possible that our results underestimate the comparative efficacy of antidepressant medications relative to psychotherapy.

Fourth, identification of possible predictors of remission was limited by the low statistical power related to the small number of available multiple-cell randomized, controlled trials, as well as the lack of variance for such variables as severity of depression and treatment duration. Regarding severity, there are conflicting reports in the literature as to whether initial depression severity predicts a differential treatment effect $(44,45)$ or whether greater baseline severity of depression predicts poorer outcomes regardless of treatment type (46). Regarding treatment duration, the percentage of patients with major depressive disorder who achieved recovery each month in one naturalistic study $(2,47)$ was $11 \%-15 \%$ during the first 3 months of follow-up before dropping to $3 \%-5 \%$ for the next 9 months. Exclusive use of multiple-cell randomized, controlled trials did not allow us to adequately address severity of depression or time required to attain optimal remission percentages with either active treatment.

Fifth, all studies in this review focused on remission at one point in time but did not require it to be sustained for any duration. As a result, the focus of this review is on full remission, not recovery. Ideally, treatment studies of major depressive disorder should examine both remission and recovery.

Sixth, although publication bias is a concern in systematic reviews, we regard the existence of unpublished multiple-cell randomized, controlled trials for major depressive disorder as highly unlikely given the relevance, cost, and high visibility of such studies. Furthermore, statistical methods to detect publication bias were not applicable to this review since it lacks a sufficient number of individual studies with a range of group sizes (48).

Last, our review does not address other important issues, such as the relative cost, speed of onset of thera- 
peutic effect, availability, and prophylactic efficacy of treatments or possible differential treatment effects on measures of functioning or core psychopathology. It also does not examine the comparative efficacy of combined pharmacological and psychological treatments. These and other issues already noted warrant further attention in a wider range of studies.

On the basis of a review of all available multiple-cell randomized, controlled trials directly comparing the efficacy of pharmacotherapy, psychotherapy, and control conditions for patients with well-defined major depressive disorder, we found that both active treatments produced higher percentages of patients with remissions and lower attrition percentages than control conditions but that these percentages were not significantly different from each other. Therefore, we conclude that both psychotherapy and pharmacotherapy may be considered first-line treatments for mild to moderately depressed outpatients seen in general medical practice or psychiatric treatment settings.

Received March 7, 2001; revision received Sept. 11, 2001; accepted March 25, 2002. From the Institute of Community and Family Psychiatry, Department of Psychiatry, Jewish General Hospital and McGill University, Montreal. Address reprint requests to Dr. Casacalenda, Institute of Community and Family Psychiatry, Department of Psychiatry, Jewish General Hospital, 4333 Côte Ste-Catherine Rd., Montreal, Quebec H3T 1E4, Canada; ncasacal@icfp.jgh.mcgill.ca (e-mail).

The authors thank the McGill Psychiatry Meta-Analysis Group for their suggestions.

\section{References}

1. Kessler RC, McGonagle KA, Zhao S, Nelson CB, Hughes M, Eshleman S, Wittchen $\mathrm{H}-\mathrm{U}$, Kendler KS: Lifetime and 12-month prevalence of DSM-III-R psychiatric disorders in the United States: results from the National Comorbidity Survey. Arch Gen Psychiatry 1994; 51:8-19

2. Keller MB, Lavori PW, Mueller TI, Endicott J, Coryell W, Hirschfield RMA, Shea T: Time to recovery, chronicity, and levels of psychopathology in major depression: a 5-year prospective follow-up of 431 subjects. Arch Gen Psychiatry 1992; 49:809-816

3. Judd LL, Akiskal HS, Maser JD, Zeller PJ, Endicott J, Coryell W, Paulus MP, Kunovac JL, Leon AC, Mueller TI, Rice JA, Keller MB: A prospective 12-year study of subsyndromal and syndromal depressive symptoms in unipolar major depressive disorders. Arch Gen Psychiatry 1998; 55:694-700

4. Wells KB, Stewart A, Hays RD, Burnam MA, Rogers W, Daniels M, Berry S, Greenfield S, Ware J: The functioning and well-being of depressed patients: results from the Medical Outcomes Study. JAMA 1989; 262:914-919

5. Broadhead WE, Blazer DG, George LK, Tse CK: Depression, disability days, and days lost from work in a prospective epidemiologic survey. JAMA 1990; 264:2524-2528

6. Mintz J, Mintz LI, Arruda MJ, Hwang SS: Treatments of depression and the functional capacity to work. Arch Gen Psychiatry 1992; 49:761-768

7. Katon W, Sullivan MD: Depression and chronic medical illness. J Clin Psychiatry 1990; 51(suppl 6):3-11

8. Greenberg PE, Stiglin LE, Finkelstein SN, Berndt ER: The economic burden of depression in 1990. J Clin Psychiatry 1993; 54:405-418
9. American Psychiatric Association: Practice Guideline for the Treatment of Patients with Major Depressive Disorder (Revision). Am J Psychiatry 2000; 157(April suppl)

10. Depression Guideline Panel: Depression in Primary Care, volume 2: Treatment of Major Depression: Clinical Practice Guideline 5: AHCPR Publication 93-0051. Rockville, Md, US Department of Health Care Policy and Research, April 1993

11. Dobson KS: A meta-analysis of the efficacy of cognitive therapy for depression. J Consult Clin Psychol 1989; 57:414-419

12. Robinson LA, Berman JS, Neimeyer RA: Psychotherapy for the treatment of depression: a comprehensive review of controlled outcome research. Psychol Bull 1990; 108:30-49

13. Gaffan EA, Tsaousis I, Kemp-Wheeler SM: Researcher alliance and meta-analysis: the case of cognitive therapy for depression. J Consult Clin Psychol 1995; 63:966-980

14. Klein DF: Flawed meta-analyses comparing psychotherapy with pharmacotherapy. Am J Psychiatry 2000; 157:1204-1211

15. Faravelli C, Ambonetti A, Palanti S, Pazzagli A: Depressive relapses and incomplete recovery from index episode. Am J Psychiatry 1986; 143:888-891

16. Evans MD, Hollon SD, DeRubeis RJ, Piasecki JM, Gove WM, Garvey MJ, Tuason VB: Differential relapse following cognitive therapy and pharmacotherapy for depression. Arch Gen Psychiatry 1992; 49:802-808

17. Thase ME, Simons AD, McGeary J, Cahalane JF, Hughes C, Harden T, Friedman E: Relapse after cognitive behavior therapy of depression: potential implications for longer courses of treatment. Am J Psychiatry 1992; 149:1046-1052

18. Paykel ES, Ramana R, Cooper Z, Hayhurst H, Kerr J, Barocka A: Residual symptoms after partial remission: an important outcome in depression. Psychol Med 1995; 25:1171-1180

19. Cornwall PL, Scott J: Partial remission in depressive disorders. Acta Psychiatr Scand 1997; 95:265-271

20. Frank E, Prien RF, Jarrett RB, Keller MB, Kupfer DJ, Lavori PW, Rush AJ, Weissman MM: Conceptualization and rationale for consensus definitions of terms in major depressive disorder: remission, recovery, relapse and recurrence. Arch Gen Psychiatry 1991; 48:851-855

21. Herceg-Baron RL, Prusoff BA, Weissman MM, DiMascio A, Neu C, Klerman GL: Pharmacotherapy and psychotherapy in acutely depressed patients: a study of attrition patterns in a clinical trial. Compr Psychiatry 1979; 20:315-325

22. Elkin I, Shea T, Watkins JT, Imber SD, Sotsky SM, Collins JF, Glass DR, Pilkonis PA, Leber WR, Docherty JP, Fiester SJ, Parloff MB: National Institute of Mental Health Treatment of Depression Collaborative Research Program: general effectiveness of treatments. Arch Gen Psychiatry 1989; 46:971-982

23. Scott AIF, Freeman CPL: Edinburgh Primary Care Depression Study: treatment outcome, patient satisfaction, and cost after 16 weeks. Br Med J 1992; 304:883-887

24. Mynors-Wallis LM, Gath DH, Lloyd-Thomas AR, Tomlinson D: Randomised controlled trial comparing problem solving treatment with amitriptyline and placebo for major depression in primary care. Br Med J 1995; 310:441-445

25. Schulberg HC, Block MR, Madonia MJ, Scott CP, Rodriguez E, Imber SD, Perel J, Lave J, Houck PR, Coulehan J: Treating major depression in primary care practice: eight-month clinical outcomes. Arch Gen Psychiatry 1996; 53:913-919

26. Jarrett RB, Schaffer M, McIntire D, Witt-Browder A, Kraft D, Risser RC: Treatment of atypical depression with cognitive therapy or phenelzine: a double-blind, placebo-controlled trial. Arch Gen Psychiatry 1999; 56:431-437

27. DiMascio A, Weissman MM, Prusoff BA, Neu C, Zwilling M, Klerman GL: Differential symptom reduction by drugs and psychotherapy in acute depression. Arch Gen Psychiatry 1979; 36: 1450-1456 
28. Weissman MM, Prusoff BA, DiMascio A, Neu C, Goklaney M, Klerman GL: The efficacy of drugs and psychotherapy in the treatment of acute depressive episodes. Am J Psychiatry 1979; 136:555-558

29. Prusoff BA, Weissman MM, Klerman GL, Rounsaville BJ: Research Diagnostic Criteria subtypes of depression: their role as predictors of differential response to psychotherapy and drug treatment. Arch Gen Psychiatry 1980; 37:796-801

30. Shea MT, Pilkonis PA, Beckham E, Collins JF, Elkin I, Sotsky SM, Docherty JP: Personality disorders and treatment outcome in the NIMH Treatment of Depression Collaborative Research Program. Am J Psychiatry 1990; 147:711-718

31. Sotsky SM, Glass DR, Shea T, Pilkonis PA, Collins JF, Elkin I, Watkins JT, Imber SD, Leber WR, Moyer J, Oliveri ME: Patient predictors of response to psychotherapy and pharmacotherapy: findings in the NIMH Treatment of Depression Collaborative Research Program. Am J Psychiatry 1991; 148:997-1008

32. Patience DA, McGuire RJ, Scott AIF, Freeman CPL: The Edinburgh Primary Care Depression Study: personality disorder and outcome. Br J Psychiatry 1995; 167:324-330

33. Schulberg HC, Madonia MJ, Block MR, Coulehan JL, Scott CP, Rodriguez $\mathrm{E}$, Black A: Major depression in primary care practice: clinical characteristics and treatment implications. Psychosomatics 1995; 36:129-137

34. Jadad AR, Moore RA, Carroll D, Jenkinson C, Reynolds DJM, Gavaghan DJ, McQuay HJ: Assessing the quality of reports of randomized clinical trials: is blinding necessary? Control Clin Trials 1996; 17:1-12

35. Stewart JW, Garfinkel R, Nunes EV, Donovan S, Klein DF: Atypical features and treatment response in the National Institute of Mental Health Treatment of Depression Collaborative Research Program. J Clin Psychopharmacol 1998; 18:429-434

36. Altshuler LL, Cohen L, Szuba MP, Burt VK, Gitlin M, Mintz J: Pharmacologic management of psychiatric illness during pregnancy: dilemmas and guidelines. Am J Psychiatry 1996; 153: 592-606

37. Priest RG, Vize C, Roberts A, Roberts M, Tylee A: Lay people's attitudes to treatment of depression: results of opinion poll for Defeat Depression Campaign just before its launch. Br Med J 1996; 313:858-859
38. Bedi N, Chilvers C, Churchill R, Dewey M, Duggan C, Fielding K, Gretton V, Miller P, Harrison G, Lee A, Williams I: Assessing effectiveness of treatment of depression in primary care: partially randomised preference trial. Br J Psychiatry 2000; 177: 312-318

39. Hotopf M, Churchill R, Lewis G: Pragmatic randomised controlled trials. Br J Psychiatry 1999; 175:217-223

40. Thase ME, Friedman ES, Fasiczka AL, Berman SR, Frank E, Nofzinger EA, Reynolds CF III: Treatment of men with major depression: a comparison of sequential cohorts treated with either cognitive-behavioural therapy or newer generation antidepressants. J Clin Psychiatry 2000; 61:466-472

41. Asnis GM, McGinn LK, Sanderson WC: Atypical depression: clinical aspects and noradrenergic function. Am J Psychiatry 1995; 152:31-36

42. Robertson HA, Lam RW, Stewart JN, Yatham LN, Tam EM, Zis AP: Atypical depressive symptoms and clusters in unipolar and bipolar depression. Acta Psychiatr Scand 1996; 94:421-427

43. Nierenberg AA, Alpert JE, Pava J, Rosenbaum JF, Fava M: Course and treatment of atypical depression. J Clin Psychiatry 1999; 59(suppl 18):5-9

44. Klein DF, Ross DC: Reanalysis of the National Institute of Mental Health Treatment of Depression Collaborative Research Program General Effectiveness Report. Neuropsychopharmacology 1993; 8:241-251

45. Elkin I, Gibbons R, Shea M, Sotsky S, Watkins J, Pilkonis PA: Initial severity and differential treatment outcome in the $\mathrm{Na}$ tional Institute of Mental Health Treatment of Depression Collaborative Research Program. J Consult Clin Psychol 1995; 63: 841-847

46. Schulberg HC, Pilkonis PA, Houck P: The severity of major depression and choice of treatment in primary care practice. J Consult Clin Psychol 1998; 66:932-938

47. Ramana R, Paykel ES, Cooper Z, Hayhurst H, Saxty M, Surtees PG: Remission and relapse in major depression: a two-year prospective follow-up study. Psychol Med 1995; 25:1161-1170

48. Gilbody SM, Song F, Eastwood AJ, Sutton A: The causes, consequences and detection of publication bias in psychiatry. Acta Psychiatr Scand 2000; 102:241-249 